ICAMS $2016-6^{\text {th }}$ International Conference on Advanced Materials and Systems

\title{
STUDIES ON THE ACID HYDROLYSIS OF CHAMOIS LEATHER WASTES
}

\author{
EMIL POPA, TUDOREL BĂLĂU MÎNDRU, MELINDA PRUNEANU, STELIAN SERGIU \\ MAIER
}

"Gheorghe Asachi" Technical University of Iași, Faculty of Textiles Leather and Industrial Management, Textile and Leather Chemical Engineering Department, 71 Dimitrie Mangeron Avenue,700500, Iaşi, Romania, email: smaier@ch.tuiasi.ro

\begin{abstract}
The present paper aims to investigate a hydrolytic method, feasible to be applied at industrial level, to turn into useful products the Chamois leather wastes, mainly the buffing dust. The efficacy of acid treatments with $0.3,0.5$ and $1.0 \% \mathrm{HCl}$ solutions, by autoclaving at $105{ }^{\circ} \mathrm{C}$, for reaction times of 6,10 and 14 hours, was determined in an attempt to optimize the hydrolysis parameters. Based on the mass balance of performed experiments, the yields of hydrolysis processes were calculated for two of the products that were separated from the final mixture: collagen hydrolysates and fats. Optimal working parameters were: a concentration of $0.5 \% \mathrm{HCl}$, and a duration of 10 hours, by simply boiling in autoclave, at $105{ }^{\circ} \mathrm{C}$. The resulted polypeptides mixture was characterized by chemical (total nitrogen content) and physical-chemical methods (FTIR spectra, EDAX). The recovered greasy matters were purified by water-solvent partition, and the specific physical-chemical indicators were determined. The main advantage of the polypeptide mixtures obtained by Chamois wastes hydrolysis consists in the fact that they are chromium-free, and can be used for a large range of industrial (foaming agents, waste water treatment, chemical auxiliaries, fillers, adhesives, blends with synthetic polymers, concrete mixtures etc.) and agricultural applications (nitrogen and sulfur slow release fertilizers, animal feeding). The grease fraction can be used in leather wet finishing, or can be further chemically modified to produce surfactants. The small amounts of solid residues which resist to the acidic hydrolysis can be used, after neutralization, as additives of concrete mixtures, in producing decorative bricks.
\end{abstract}

Keywords: Chamois buffing dust, acid hydrolysis, polypeptide and greasy matters recovery.

\section{INTRODUCTION}

The stringent enforcement of the environmental protection has prompted technologists and scientists to re-look at the waste management and transform tannery solid and liquid waste materials into usable, value-added products. Thus, the advanced processing of the leather manufacturing solid wastes leads to the obtaining of proteinbased materials that can be used for new building materials (concrete, thermal insulation panels and noise absorption panels (Sathish Kumar et al., 2015, UNIDO, 2000; Mafia et al., 2002), as biofertilizers to improve the soil quality (Zainescu et al., 2012), as additions for pigment pastes to obtain finishing films (Popa et al., 2016), composts (Sundar et al., 2011), biodegradable bioplastic composite materials (Deselnicu et al., 2014; Alexy et al., 2003), dyes adsorbents (Carpenter et al., 2013) or the production of biodiesel biofuel (Kolomaznik et al., 2009).

Only sheepskin is used in the production of genuine Chamois leather, due to its naturally open fibre structure. The manufacturing company has adhered to the framework agreement of the environmental reporting standard in the European leather and tanning industry, by using non toxic chemicals in any tanning treatments. This fact represents a major advantage for using the Chamois leather waste in hydrolysis processes, thus allowing for useful waste components to be recovered and then turned into eco-efficient bioproducts.

Accordingly, in the present paper we analyzed the yield and the mass balance of the hydrolysis process performed in acid conditions, at different concentrations of the $\mathrm{HCl}$ solution $(0.3 \% ; 0.5 \%$ and $1.0 \%)$ and durations of the hydrolysis $(6,10$, and 14 hours). 
The paper also deals with the extraction of useful components from the mixture resulted from the acid hydrolysis of the Chamois leather wastes, with the purpose of their further exploitation.

\section{EXPERIMENTAL DATA AND DISCUSSIONS}

The experimental work was carried out on Chamois leather buffing dust. According to the current standards, the following analyses were performed to characterize the buffing dust: the total nitrogen content $(\mathrm{TKN}=10.82 \%)$, the hide matter $(\mathrm{HM}=63.64 \%$ according to SR EN ISO 5397-1996); the mineral substances content (MS=13.17\% according to SR EN ISO 4047-2002), the extractable fatty matters content $(\mathrm{EFM}=11.70 \%)$, and by deduction, other organic substances content was calculated $(\mathrm{OS}=11.49 \%)$, which includes the combined fatty matters. All the above mentioned values were expressed on the leather dry matter basis. Thus, the mass balance for the leather substance subjected to hydrolysis can be stated by the following equation (1):

$\%$ Hide dry matter $=\% H M+\% M S+\% E F M+\% O S$

In order to obtain a protein hydrolyzate in the laboratory, starting from the Chamois leather buffing dust, an experimental protocol was applied, with the purpose of analyzing the hydrolysis yield and the mass balance, dependent on the acid concentration $(0.3 \%, 0.5 \%, 1 \%)$ and on the treatment time $(6,10,14$ hours), according to a procedure applied for all hydrolysis experiments: 50 grams of Chamois buffing dust $(\mathrm{BDDM}=43.9901 \mathrm{~g}$ dry matter, of which $\mathrm{BDPM}=27.9952 \mathrm{~g}$ protein matter $)$ and 1 liter of $\mathrm{HCl}$ solution with a given concentration were introduced in an autoclave; the reaction mass was heated to $105{ }^{\circ} \mathrm{C}$, for the time duration established by preliminary hydrolysis tests. The resulted product, in the form of a finely segregated gel, was centrifuged at $3000 \mathrm{RCF}$, for 30 minutes; the solid residue was collected and the supernatant was subjected to a liquid-liquid phase separation by using a mixture of 5:3 water : non-polar solvent (trichloroethylene), followed by vigorous stirring for 1 hour in a Vortex mixer, heating up to $60-70{ }^{\circ} \mathrm{C}$ and cooling down for 12 hours at room temperature for phase separation. Each separated layer was dried to constant weight in the oven at $100 \pm 5{ }^{\circ} \mathrm{C}$ and then the dry substance mass was determined for each separated layer (Figure 1).

The mass balance for all hydrolysis variants was calculated according to equation (2), and the hydrolysis yield from equation (3). The dried product resulted from the aqueous layer, which contains hydrolyzed collagen fragments (polypeptides, oligopeptides, amino-acids) was analysed by infrared spectroscopy and X-ray dispersive energy (EDAX) spectral analysis. The total nitrogen content was determined by Kjeldahl method. In order to screen the collagen fragments by their molecular weight, the samples were dialysed using SpectraPor $3(3.5 \mathrm{kDa})$ and SpectraPor $6(1.6-2 \mathrm{kDa})$ membranes (Spectrum Laboratories Inc., Canada). Table 1 resumes the hydrolysis yield and the mass balance for the experimental variants.

Mass Balance $\%=\frac{T S(g)+E F M(g)+C F M(g)+T I(g)}{B D D M(g)} \cdot 100 \quad[\%]$, 
ICAMS 2016 $-6^{\text {th }}$ International Conference on Advanced Materials and Systems

where: DM is the total dry mass of the cumulated layers, TS is the total mass of soluble substances, EFM is the extractable fatty maters, CFM is the fatty matters combined with the collagen, TI is the total insoluble content, and BDDM is the dry matter content of the analyzed buffing dust $(=43.9901 \mathrm{~g})$.

Hydrolysis yield $\%=\frac{P D M(g)}{B D P M(g)} \cdot 100 \quad[\%]$,

where PDM is the polypeptides dry mater content of the samples, and BDPM is the buffing dust protein matter content $(=27.9952 \mathrm{~g})$.

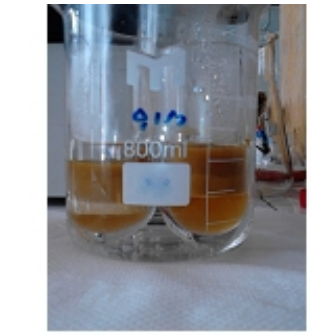

3 phase separation with a concentration of $0,3 \% \mathrm{HCl}$

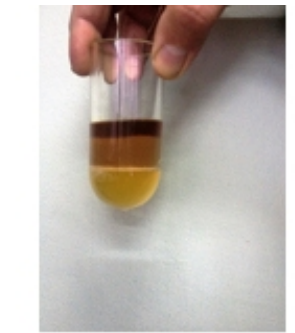

4 phase separation with a concentration of $0,5 \% \mathrm{HCl}$

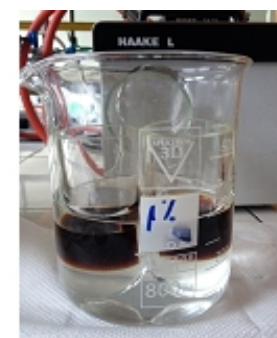

2 phase separation with a concentration of $1 \% \mathrm{HCl}$

Figure 1. Liquid - liquid phase separation

Table 1. Hydrolysis yield and the mass balance for the experimental variants

\begin{tabular}{|c|c|c|c|c|c|c|c|c|c|}
\hline \multirow{3}{*}{$\begin{array}{l}\text { Components } \\
\text { mass (g) }\end{array}$} & \multicolumn{9}{|c|}{$\mathrm{HCl}$ concentration (\%) / Hydrolysis duration (hours) } \\
\hline & \multicolumn{3}{|c|}{0.3} & \multicolumn{3}{|c|}{0.5} & \multicolumn{3}{|c|}{1.0} \\
\hline & 6 & 10 & 14 & 6 & 10 & 14 & 6 & 10 & 14 \\
\hline TS & 21.7901 & 18.9226 & 18.5824 & 11.1203 & 13.8514 & 13.2096 & 28.2237 & 30.4022 & 31.3363 \\
\hline PDM & 2.5082 & 2.2822 & 2.4138 & 2.1045 & 3.1054 & 3.1029 & 3.2848 & 4.1954 & 4.9391 \\
\hline CFM & 10.8342 & 12.0456 & 14.1696 & 23.2162 & 26.3522 & 19.2131 & 2.9821 & - & - \\
\hline EFM & 3.2313 & 5.5484 & 5.8216 & 0.8932 & 1.3507 & 5.2323 & 0.8236 & 5.9421 & 6.2816 \\
\hline TI & 5.8726 & 5.4151 & 2.9605 & 6.2641 & 2.3974 & 4.3462 & 11.7946 & 7.2099 & 5.7627 \\
\hline BDDM & 41.7282 & 41.9317 & 41.5341 & 41.4938 & 43.9517 & 42.0012 & 43.8240 & 43.5542 & 43.3806 \\
\hline $\begin{array}{l}\text { Hydrolysis } \\
\text { yield, (\%) }\end{array}$ & 8.96 & 8.15 & 8.62 & 7.52 & 11.09 & 11.08 & 11.73 & 14.99 & 17.64 \\
\hline $\begin{array}{l}\text { Mass } \\
\text { balance, }(\%)\end{array}$ & 94.86 & 95.32 & 94.42 & 94.33 & 99.91 & 95.48 & 99.62 & 99.01 & 98.61 \\
\hline
\end{tabular}

Figure 2 illustrates the dependence of the total nitrogen content and of the hydrolysate proteins content on the $\mathrm{HCl}$ concentration and on the hydrolysis time. With a concentration of $0.3 \% \mathrm{HCl}$, a protein hydrolysate content of $12.99 \%$ is obtained after 14 hours, with a concentration of $0.5 \% \mathrm{HCl}$, a protein hydrolysate content of maximum $23.49 \%$ is obtained after 14 hours. The hydrolysis with $1 \% \mathrm{HCl}$ provides the highest content of hydrolyzed proteins, i.e. $50.30 \%$ after a 14 hours treatment.

In order to assess the molecular weight of the resulting protein forms, the dialysis with SpectraPor $3(3.5 \mathrm{kDa})$ and SpectraPor $6(1.6-2 \mathrm{kDa})$ membranes was performed. For the hydrolysis variants with $1 \% \mathrm{HCl}$, no matter the duration, highly fragmented collagen forms are obtained, with a molecular weight of less than $1.6 \mathrm{kDa}$. The 
hydrolysis variants with $0.5 \% \mathrm{HCl}$ provide molecular weights in the range $1.6-3.5$ $\mathrm{kDa}$, which, correlated with the hydrolysis yield, offer results in accordance with the aimed purpose. The $0.3 \% \mathrm{HCl}$ variants offer less satisfying results correlated with the hydrolysis yield, even if the molecular weights are included in the expected range.

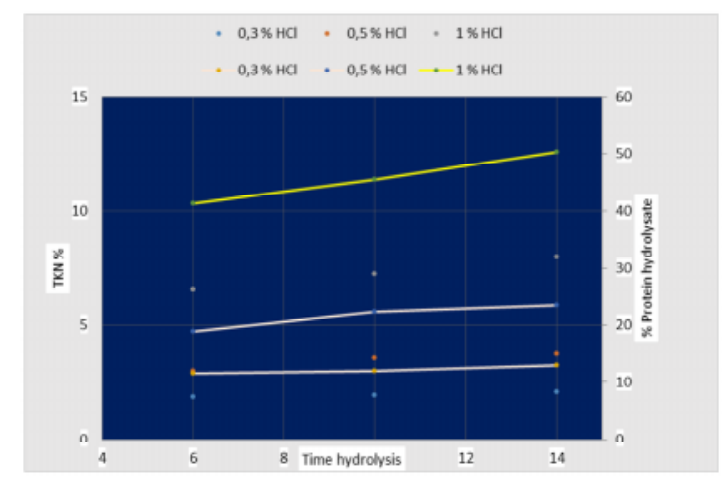

Figure 2. The TKN and the proteinshydrolysate content in the aqueous phase dependence on the $\mathrm{HCl}$ concentration and on the hydrolysis duration

The EDAX charts are registered both for the Chamois leather powder and for the aqueous phases separated as described. The presence of the constituent $\mathrm{C}, \mathrm{N}, \mathrm{O}$ chemical elements can be noticed (Figure 3a) and also that of Na, B, Ca, Al, Si cations, which confirm the high content of mineral substances in the Chamois leather. They are present as sodium chloride, calcium oxide and traces of alumina and silicon oxide. Of all the mineral elements, the highest one is Boron, $18.6 \%$, which can be explained by the fact that at the end of the oil tanning operation, in order to fix/mix the fatty substances with the functional groups of the collagen matrix in the cow-hide dermis, and also in order to shorten the oxidation stage, the modern technologies entail a rapid oxidation stage, using different oxidizing agents, such as perborate compounds (Zhou et al., 2003). Figures 3 (b, c and d) shows the EDAX charts for the collected aqueous phases. Regardless the hydrolysis version, the compounds of the $\mathrm{Na}, \mathrm{B}, \mathrm{Al}, \mathrm{Si}, \mathrm{Ca}$ cations are found in the aqueous phase, but the highest content is found for the concentration of $0.5 \% \mathrm{HCl}$. On the other hand, the acid concentration and the hydrolysis time have a major influence upon the degree of hydrolysis. The registered data show the advance of the hydrolysis at the same time with the increase of the acid concentration and of the hydrolysis duration, the aqueous phase is enriched in hydrolysate protein forms. Thus, for the $0,3 \% \mathrm{HCl}$ version, in 14 hours, the nitrogen content is of $1.68 \%$; With a concentration of $0,5 \% \mathrm{HCl}$, it reaches the value of $3.97 \%$, and for $1 \% \mathrm{HCl}$, the nitrogen content is $6.64 \%$. The registered values can be compared with those analytically determined by the Kjeldahl method.

Compared with the initial untreated sample, the IR spectra of the the aqueous protein phase (layer 1) are characterized by the distorsion of the specific peaks for amides I, II and III. The spectra in the figure 4 show a shift of the characteristic peaks in the range $3450-3300 \mathrm{~cm}^{-1}$ (of $\mathrm{NH}+\mathrm{OH}$ groups) and of $3200 \mathrm{~cm}^{-1}$ spectral band (of free $\mathrm{OH}$ groups) of the initial sample to $3100 \mathrm{~cm}^{-1}$, and $3000 \mathrm{~cm}^{-1}$ bands respectively, which could indicate possible new intermolecular interactions through hydrogen bonds. 


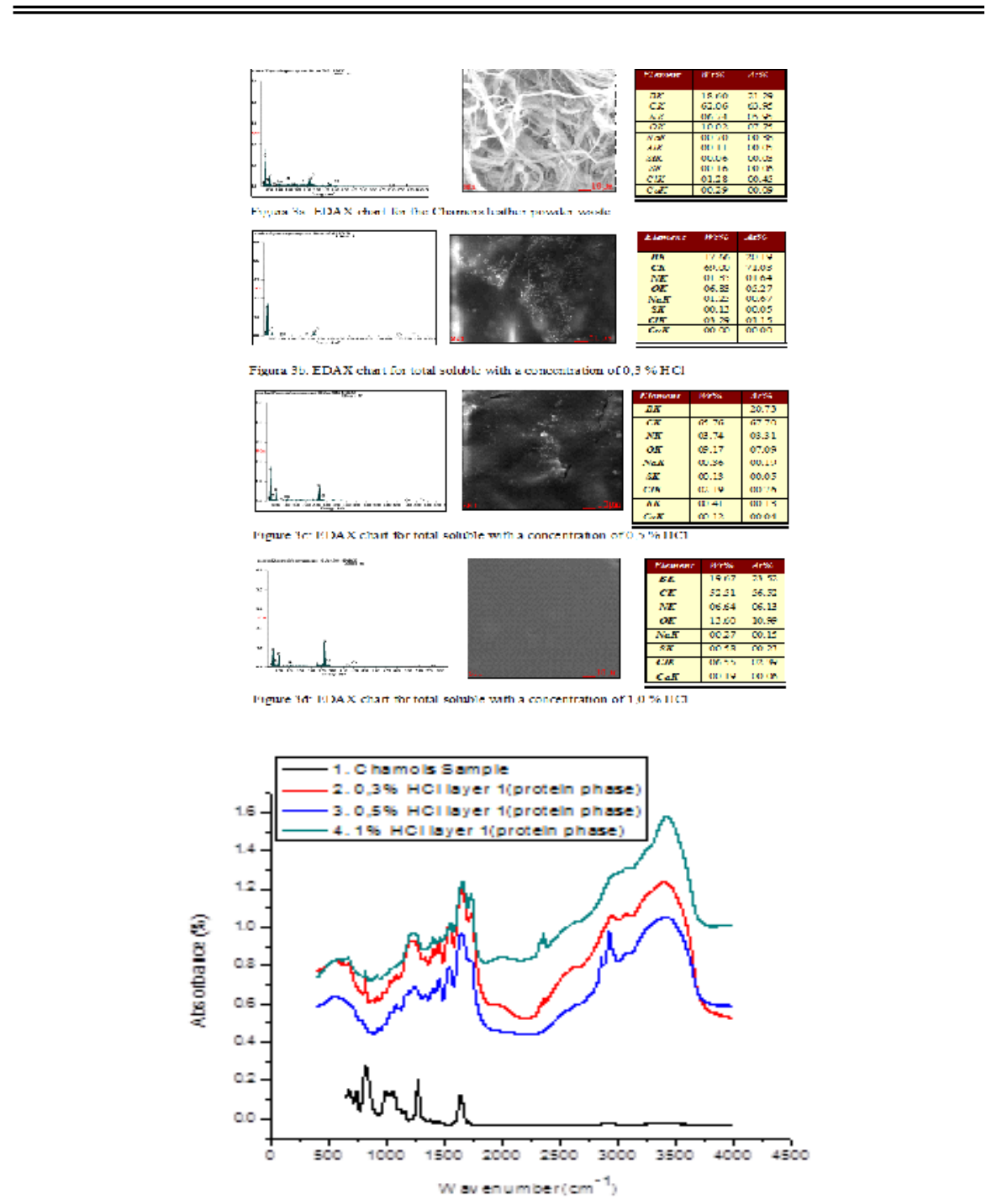

Figure 4. IR Spectra of layer 1 hydrolysates

It can be also seen a decrease in signal intensity of spectral bands characteristic to CO groups from amide I located between $1650-1650 \mathrm{~cm}^{-1}$, of $\mathrm{NH}$ groups from amide II located between $1555-1545 \mathrm{~cm}^{-1}$, and of $\mathrm{NH}+\mathrm{CH}$ groups from amide III located between $1240-1230 \mathrm{~cm}^{-1}$, for the hydrolisate samples $(2,3,4)$ compared to the control sample (1). 


\section{CONCLUSIONS}

As a result of the acid hydrolysis of the Chamois leather waste samples, it can be concluded that:

1. The processing of sheepskins in order to obtain Chamois leather implies the use of auxiliaries with a low toxic potential, which represents an advantage for the recovery of useful components with a positive impact on the environment.

2. For the $1 \% \mathrm{HCl}$ hydrolysis, regardless the treatment time, highly fragmented collagen forms are obtained, with a molecular weight of less than $1.6 \mathrm{kDa}$. The variants with $0.5 \% \mathrm{HCl}$ result in molecular weights of more than $1.6 \mathrm{kDa}$, which correlated with the hydrolysis yield, offer results in accordance with the aimed purpose. The $0.3 \% \mathrm{HCl}$ concentration, even if it indicates molecular weights included in the expected range, correlated with the hydrolysis yield, offers less satisfying results.

3. After the hydrolysis treatment, the solvent extraction of the phases which contain useful components (peptides, oils, fats) makes it possible to be subsequently separated and used as biocomponents for different applications.

\section{Acknowledgements}

This work was performed within the framework of the project PNII-PT-PCCA2013-4, nr. 216 / 2014, with the title "Sistem inovativ de produse si tehnologii destinat stimularii cresterii eco-eficien ei industriei de pielărie" (PROECOPEL) (TUIASI - P2).

\section{REFERENCES}

Alexy, P., Bakos, D., Crkonova, G. et al. (2003), "Poly(vinyl alcohol)-collagen hydrolysate thermoplastic blends: II. Water penetration and biodegradability of melt extruded films", Polymer Testing, 22, 811-818.

Carpenter, J., Sharma, S., Sharma, A.K. et al. (2013), "Adsorption of Dye by Using the Solid Waste from Leather Industry as an Adsorbent", International Journal of Engineering Science Invention, 2(1), 64-69.

Deselnicu, D.C., Militaru, G. and Deselnicu, V. (2014), "Obtaining of Biodegradable Plastic Materials", Revista de Materiale Plastice, 51(1), 72-74.

Kolomaznik, K., Barinova, M. and Furst, T. (2009), "Possibility of using tannery waste for biodiesel production". Journal of American Leather Chemists Association, 104, 177-182.

Mafia, G.J., Slomiana, M. and Davis, J.F. (2002), "Recent advances in collagen based technologies", Journal of American Leather Chemists Association, 97, 74-82.

Popa, E., Bălău Mîndru, I., Pruneanu, M. et al. (2016), "Potential use of collagen hydrolysates from chamois leather waste as ingredient in leather finishing formulations", Annals of the University of Oradea fascicle of textiles, Leatherwork, 17(2), 203-209.

Sathish Kumar, V. and Vijayaravind, S. (2015), "Utilization of Tannery Shredded Waste as Fine Aggregate in Concrete", International Journal of Engineering Research \& Technology (IJERT), 4(04).

Sundar, V.J., Gnanamani, A., Muralidharan, C. et al. (2011), "Recovery and utilization of proteinous wastes of leather making: a review", Reviews in Environmental Science and Bio/Technology, 10, 151-163.

UNIDO (2000), "Fourteenth Session of the Leather and Leather Products Industry Panel", Zlin, Czech Republic, 1-58.

Zainescu, G., Deselnicu, D.C., Ioannidis, I. et al. (2012), "New Versatile Conversion Technology for Wet White Waste Transformation to Biofertilisers", Proceedings of the 4th International Conference on Advanced Materials and Systems - ICAMS 2012, 71-76.

Zhou, H., Zhang, X., Chen, J., Jiang, X. et al. (2003), "Study of oxidating mechanism and development of technology about the unsaturated lipoids (II) - Characteristic properties of reaction and development of technology about lipoidic free radical [J]"; China Leather, 13, The Key Laboratory of Leather Chemistry and Engineering of Ministry of Education, Sichuan University, Chengdu 610065. 